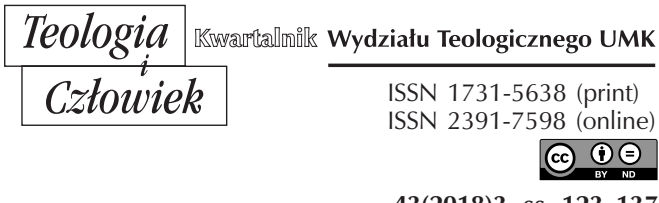

43(2018)3, ss. $123-137$

KS. PAWEK SZCZEPANIAK

\title{
PRÓBA ZNALEZIENIA DIALOGU MIĘDZY SZTUKĄ WSPÓŁCZESNĄ A KOŚCIOŁEM W PIERWSZYCH REFLEKSJACH ESTETYCZNYCH G. B. MONTINIEGO
}

DOI: http://dx.doi.org/10.12775/TiCz.2018.030

Streszczenie. Przełom dziewiętnastego i dwudziestego stulecia przyniósł początek rozłamu między teologią a sztuką. Artyści w swych poszukiwaniach sięgają do nowych źródeł inspiracji jakimi są nauka i wynalazki, ukazujące siłę człowieka i pęd ku zdobyciu wiąż kurczącego się świata. Ów rozłam negatywnie wpłynął na sztukę sakralną, która straciła ducha nowości. Zamknięta na nowe prądy stała się machinalnym powtarzaniem już istniejących nurtów historii sztuki. Manifesty futurystów, jeszcze bardziej zakleszczyły niechęć i niezrozumienie świata teologii stojącego na przeciw artysty wyznającego duchowość pędu. W pęknięciu powstałym w wyniku ruchów i teorii artystycznych młody kapłan G. B. Montini poszukuje mostów, które umożliwią dialog, a co więcej, dadzą kierunek odnowionej sztuce sakralnej. Sztuce która pojedna geniusz artysty z geniuszem Stwórcy.

Słowa kluczowe: sztuka sakralna; Montini; Beuron; Marinetti; futuryzm.

Abstract. An Attempt to Find a Dialogue Between Contemporary Art and the Church in the First Aesthetic Reflections of G. M. Montini. The turn of the 19th and 20th centuries brought the beginning of a split between theology and art. In their search, artists reach for new sources of inspiration, which are science and inventions showing human strength and the drive to get the binding of a shrinking world. That split negatively affected the sacred art that lost the spirit of novelty. Closed to new trends, it 
has become a mechanical repetition of the existing currents of art history. Futurist manifestations have intensified the dislike and misunderstanding of the world of theology against the artist who confesses the spirituality of the momentum. In the crack created as a result of movements and artistic theories, the young priest G. B. Montini looks for bridges that will enable the dialogue and, moreover, will give direction to the renewed sacred art. The art that reconciles the genius of the artist with the genius of the Creator.

Key words: Sacred art; Montin; Beuron; Marinetti; futurism.

Koniec XIX i początek XX wieku w zawrotnym tempie zmieniły społeczeństwa Europy. Nowe odkrycia naukowe i niespotykany dotąd pęd techniki zrewolucjonizowały postrzeganie świata. Owa rewolucja objęła również świat kultury i sztuki, który jak w każdej epoce, jest odzwierciedleniem ludzkich pragnień i działań. Sztuka przełomu wieków przygląda się darwinowskiej ewolucji, a z czasem za Freudem, sięgnie do głębi ludzkiego umysłu, aby tam poszukiwać szczęścia i piękna. Spychana wciąż ku pustce duchowej w 1891 r. przemówi w jednym z artykułów słowami G. Segantiniego: „sztuka musi wypełniać pustkę pozostawioną w nas przez religie. Sztuka przyszłości musi objawić się jako nauka ducha, jako że dzieło sztuki jest jego objawieniem"1. W tym samym czasie Kościół będący częścią społeczeństwa stanął przed wieloma pytaniami i wyborami podyktowanymi przez zmieniający się świat. Jednym z problemów był (i nadal jest) stosunek do sztuki, która wraz z końcem dziewiętnastego stulecia stała się niezależną formą i myślą kręgów artystycznych. Sztuka nowoczesna (Modernizm) począwszy od Impresjonizmu oddziela się od środowiska teologicznego, przechodząc transformację niekoniecznie do końca zrozumianą i zaakceptowaną przez Kościół. Rodząca się awangarda stwarza nowy język sztuki, odrzucając tym samym dotychczasowe schematy i stając się częścią coraz bardziej zsekularyzowanego społeczeństwa - społeczeństwa chcącego „sztuki dla siebie”, sztuki, która będzie w stanie odzwierciedlić przemiany, niepokoje społeczne i pragnienia ludzkie.

1 „Larte deve rimpiazzare il vuoto lasciato in noi dalle religioni. Larte dell'avvenire dovrà apparire come scenza dello spirito, essendo l'opera d'arte la rivelazione di esso", G. Segnantini, Pensieri d'artisti, w: Archivi del divisionismo, red. M. T. Fiori, Roma 1969 , t. I, s. 337. 
Autor w niniejszym artykule spróbuje ująć problem budowania mostów między światem sztuki a Kościołem, którego podjął się Giovanni Battista Montini, późniejszy papież Paweł VI w swoich dwóch pierwszych, opublikowanych na łamach czasopism, refleksjach. Ponieważ teksty nie zostały dotąd opublikowane w języku polskim, autor przytacza ich większą część wraz z tłumaczeniem oraz tekstem oryginalnym, aby ukazać w miarę możliwości pełny obraz myśli Montiniego. Papież Paweł VI będąc człowiekiem kultury od młodości „dopuszcza” lekturę autorów różnego pochodzenia. Obok wielkich mistrzów literatury, nie brakuje w jego bibliotece autorów francuskich takich jak: Jean Guitton, Jacques Maritain, o. Henri de Lubac, Jean Daniélou, Yves-Marie Congar, Luis-Joseph Lebret, Charles Journet czy Maurice Zundel. Owa szeroka lektura pozwala Montiniemu na znalezienie punktów do refleksji na temat trudnego i w owym momencie historii prawie niemożliwego pojednania dwóch kultur: tradycyjnej i katolickiej z kulturą modernistyczną ${ }^{2}$. Początki refleksji młodego Montiniego nad sztuką są o tyle ciekawe, iż stanowią świadectwo poszukiwań teologa a nie specjalisty z dziedziny dóbr kultury, czy też historyka sztuki. Oczywiście, nie są one pozbawione prywatnego, wyrobionego gustu, uprzedzeń czy też preferencji personalnych. Jednak Montini wykazuje niezwykłą intuicję i zaangażowanie we wznoszeniu mostów między artystą modernistycznym a sztuką sakralną․

\section{SZANSA DLA SZTUKI SAKRALNEJ. BENEDYKTYŃSKA SZTUKA BEURON}

Pierwszym artykułem w którym Montini przedstawia refleksje na temat sztuki, jest opublikowany w styczniu 1929 r. w „Studium” - czasopiśmie uniwersyteckim założonym przez samego Montiniego - artykuł Larte di Beuron 4 . Owe przemyślenia są owocem podróży odbytej latem 1928 r. śladami opactw benedyktyńskich Europy Północnej, które prze-

2 Por. P. Poupard, Le dialogue, Paul VI et les cultures contemporaines, w: La journée détudies Paris, 13 décembre 2005, red. G. Archetti, Brescia 2007, s. 54-55.

3 Por. G. L. Tusini, Una non facile conciliazione, w: Vita culturale e idee sull'arte negli anni del Vaticano II, red. E. Marchetti, G. L. Tusini, Roma 2011, s. 40-41.

${ }^{4}$ G. B. Montini, Larte di Beuron, „Studium” 25 (1929) 1, s. 33-37; późniejsze wydanie: tenże, L’arte di Beuron, „Istituto Paolo VI. Notiziario” 16 (1988), s. 7-10. 
żywają swój renesans. Nie jest to jego pierwsze zetknięcie ze światem duchowości i kultury benedyktyńskiej. Już 1919 r. w jednym z artykułów opublikowanych w „La Fionda” zwraca uwagę na bogactwo wypracowane i pozostawione we Włoszech i Europie przez benedyktynów ${ }^{5}$. Jak wynika z listów wysłanych do rodziny ${ }^{6}$, będących swoistą dokumentacją podróży, młody kapłan zwiedza między lipcem a sierpniem belgijskie opactwo Maredsous, założone w 1872 r., reprezentujące styl neogotycki. Następnie opactwo Saint-André Brugia (Belgia) i Mont-César w pobliżu Leuven. 2 sierpnia Montini zwiedza opactwo Maria Laach w Niemczech, stanowiące istotny przykład sztuki romańskiej. Siódmego sierpnia zatrzymuje się w klasztorze Beuron w Baden-Württemberg w diecezji Fryburskiej, będącym jedną z ważniejszych szkół sztuki sakralnej na przełomie XIX i XX w. Założona w 1868 r. przez Desideriusa Lenza (1832-1928), Gabriela Wügera (1829-1892) oraz Lukasa Steinera (1849-1906) szkoła, ma na celu odnowienie sztuki sakralnej. Dzięki współprzenikaniu się idei artystycznych z myślą teologiczną, powstaje nurt, który według S. M. Vismary, jest dla sztuki tym, czym śpiew gregoriański dla muzyki. Wszystko to osiągnięte dzięki prostocie w której odnajduje się mistycyzm7. Jej główny założyciel Desiderius Lenz swoją wizję sztuki sakralnej bazuje na sztuce egipsko-babilońskiej oraz regułach geometrycznych, wyraźnie widocznych w dziełach. W swych pismach stawia tezę, że istniała niegdyś sztuka sakralna oparta o dogmaty, która przestrzegała reguły proporcji i harmonii oraz, iż Egipcjanie byli w posiadaniu owej reguły, która przez dziesiątki lat ery chrześcijańskiej została zatracona. Zdaniem Lenza misją artystów jest odzyskanie owych zasad. Sztuka ma być prosta, bo to właśnie w prostocie jest jej szlachetność ${ }^{8}$. Antyczna sztuka chrześcijańska powinna się narodzić do nowego życia w swoim duchu a nie w formie, która ma się udoskonalać w nurcie artystów antycznych ${ }^{9}$.

${ }^{5}$ Por. tenże, Spunti apologetici, w: Scritti giovanili, red. C. Trebeschi, Brescia 1979, s. $138-139$.

${ }^{6}$ Zob. tenże, Lettere ai familiari (1919-1943), t. II (1928-1943), red. N. Vian, Brescia-Roma 1968, s. 546-559.

7 Por. S. M. Vismara, La nuova arte di Beuron, Roma 1913, s. 14-15.

8 Por. D. Lenz, Canone Divino. Larte e la regola della Scuola di Beuron, red. P. Martore, Castelvecchi 2015, s. 46-53.

9 Por. D. Lenz, Canone Divino, s. 66. 
Według Montiniego, to właśnie szkoła Beuron jest jednym z lepiej zdefiniowanych nurtów współczesnej sztuki sakralnej. Nawet jeśli na początku rozważań podkreśla, iż sam podchodzi do niej nieco sceptycznie twierdząc:

Nie jestem bezwarunkowym wielbicielem szkoły Beuron. Wyznaję również, że im bardziej się jej przyglądam, tym bardziej mi się ona podoba i wydaje mi się, że sztuczne elementy, których jest ona pełna, są uzupełniane $\mathrm{z}$ własnego powodu, a przynajmniej zawsze są bardziej wtórne niż znacząca wartość tej sztuki ${ }^{10}$.

Wraz z odrodzeniem benedyktynów w Niemczech, rozwija się więc sztuka sakralna. Co więcej, ta z Beuron „pobudza do myślenia”"11. Nawet jeśli nie wydała znaczącej liczby artystów i dzieł, to według młodego kapłana, są one wystarczające do zdefiniowania jej stylu, który ma swoją kontynuację w takich artystach, jak: Reinhold Teutenberg, Notker Becker, Adalberto Gresnicht. Próbując nakreślić styl cytowanej szkoły, Montini posługuje się przykładem krypty z Monte Cassino.

Wschód jest tu, wewnątrz, tak, nawet bardziej niż mogłoby to wydawać się przy pierwszym wrażeniu; tak jak jest to w całej sztuce Beuron. Widać to wyraźnie w wielu motywach dekoracyjnych dokładnie przeniesionych z fryzów babilońskich i egipskich i w wielu liniach romańsko bizantyjskich $^{12}$.

Czujne oko Montiniego zwraca uwagę na kopiowanie stylu pochodzącego wprost z cywilizacji archaicznych, ze sztuki babilońskiej, bizantyjskiej i wczesnochrześcijańskiej, który budzi w nim zrozumiałe pytanie

10 „Io non sono un incondizionato ammiratore della Scuola di Beuron. Ma confesso anche che più la osservo e più mi piace, e mi pare che gli elementi artificiosi di cui è piena si stemperino in una loro propria ragione di essere, o almeno riescano sempre più secondari rispetto al valore significativo di quest'arte”. G. B. Montini, Larte di Beuron, s. 33.

11 „Beuron fa pensare”, G. B. Montini, Larte di Beuron, s. 33.

12 „L'Oriente cè qui dentro, si, anche più che non dicesse la prima impressione; come cè in tutta l'arte di Beuron. Cè evidente in tanti motivi decorativi esattamente riportati da fregi babilonesi ed egiziani, e in parecchie linee di romanico bizantino". G. B. Montini, Larte di Beuron, s. 34 . 
i wątpliwość: „czy to przynależy do chrześcijaństwa”?13 „Inne szczegóły - kontynuuje, omawiając statuy św. Benedykta i św. Scholastyki dwie nieruchome, sztywne siedzące postacie, dwa cedrowe posągi, świętego Benedykta i świętej Scholastyki, które można opisać od razu: twarz z kości słoniowej, bursztynowe oczy, broda świętego Benedykta i kwef świętej Scholastyki ze srebra" ${ }^{14}$. Inne szczegóły - kontynuuje omawianie postaci św. Benedykta i św. Scholastyki - symboliczne i dekoracyjne detale w ramach całości zwiększają zdumienie i niepewność. Mocne odniesienie do kwestii tych posągów i ich niezwykła, ostra stylizacja sprawiają, że myślimy o idolu: to jest punkt sztuki Beurona, który chciałby być bardziej doskonały, a pozostawia większe niezadowolenie. Nie wszystko jednak podlega negatywnej ocenie. Fryz przedstawiający procesję świętych w kierunku grobu św. Benedykta i Scholastyki „jest pełen humanizmu i pobożności chrześcijańskiej, i znajduje się wśród tych przepięknych obiektów, nawet jeśli mniej charakterystycznych, które sztuka Beuron wyprodukowała"15.

Powtarzająca się hieratyczność spowodowana wpływem sztuki egipsko-babilońskiej oraz stylizacji bizantyjskiej, jest według młodego kapłana łagodzona formami zaczerpniętymi z katakumb wczesnochrześcijańskich, ze stylu romańskiego oraz włoskiego Quattrocenta. Owe wpływy widoczne są w szczególności w pierwszym dziele Lenza, kaplicy św. Maura położonej nieopodal Beuron. „Ale nigdy nie spotykamy ani gotyku ani renesansu: dwóch największych nurtów w sztuce śródziemnomorskiej, które zostały porzucone. Próba ta pozostawia wątpliwości, a wszystko to wcześniej niż artystyczne i religijne spektrum szkoły, pokazuje, jeśli nic więcej, to zuchwałość pewnej nowości, uważanej za niemożliwą"16.

13 „ma questo è roba cristiana?”, G.B. Montini, Larte di Beuron, s. 34.

14 „due immobili, fisse, rigide figure sedute; due statue di cedro, san Benedetto e santa Scolastica; di cui subito ti vien fatta la descrizione: faccia d'avorio; occhi d'ambra; barba di san Benedetto, e soggolo di santa Scolastica, d'argento", G. B. Montini, Larte di Beuron, s. 34 .

15 „[...] è piena di umanità e di religiosità cristiana, ed è fra le più belle cose, anche se meno caratteristiche, che l'arte di Beuron abbia prodotto", G.B. Montini, Larte di Beuron, s. 35.

${ }^{16}$ „Ma mai incontriamo né gotico, né Rinascimento: le due più grandi correnti dell'arte mediterranea sono abbandonate. Tentativo questo, che lascia dubitosi e tutta 
Wraz z cytowaną nowością „zniknęło wiele grzechów nowoczesnej sztuki sakralnej: jak ten fundamentalny: zatrzymanie spojrzenia na sobie a nie wprowadzenia go w tajemnice Niewidzialnego; również ten, bardzo rozpowszechniony: nieznajomość prawdziwego języka teologicznego i symboliki chrześcijańskiej, poprzez zastąpienie ich, nie wiem jak dziwną, religijnością artysty" ${ }^{17}$. Tak więc, sztuka Beuron nawet jeśli nie całkiem perfekcyjna, jest w opinii Montiniego zdolna do pobudzenia wiary. Jest sztuką, która wprowadza w świat zatraconego mistycyzmu:

Jest ona czystą sztuką sakralną. Nie wzbudza innej emocji, aniżeli pobożność. Nie odsłania innych scen jak tylko te związane $\mathrm{z}$ wiarą. [...] Aby do tego dojść, poniosła poważne wyrzeczenie: straciła całkiem ruch. [...] Zrezygnowała ponadto $\mathrm{z}$ nieskończonych zasobów techniki kolorystycznej: jej kolory, zawsze zharmonizowane z dużym gustem, są płaskie i zawsze jednorodne w odcieniu, który jest wstrzemięźliwy i linearny ${ }^{18}$.

Esencjalność, hieratyczność, zachowawczość w kolorze, surowość w formie. Owe cechy sztuki Beuron czynią ją mistyczną, zdolną do pobudzenia ducha i poprowadzenia go ku boskiej nieskończoności. Wraz z estetyką Lenza powróciła, według Montiniego, sztuka chrześcijańska pełna mistycyzmu i wiary:

Ta sztuka, nie rozprasza. Pozwala medytować, pozwala modlić się. Mistycyzm objawił się w swoich formach, a przemienienie, najwyższa zasada życia nadprzyrodzonego i kultu liturgicznego stało się jej artystyczną

prima della portata artistica e religiosa della scuola: ma che mostra, se non altro, laudacia d'una novità creduta impossibile", G. B. Montini, L'arte di Beuron, s. 36.

17 „[...] ma sono scomparsi anche molti grandi peccati dell'arte sacra moderna: come quello, fondamentale, di fermare a sé lo sguardo e non introdurlo agli arcani dell'Invisibile; e quello, diffusissimo, di non conoscere più il linguaggio vero della teologia e del simbolismo cristiano, per sostituirvi non so che strana religiosità dellartista", G. B. Montini, Larte di Beuron, s. 34.

18 „Essa é arte religiosa pura: essa non sucita altra emozione che la devozione; essa non rivela altre scene che quelle della fede. Anzi, per arrivare a questo sè imposta gravi sacrifici: ha perduto affatto di movimento. [...] Ha rinunciato inoltre a infinite risorse della tecnica coloristica: le sue tinte, armonizzate sempre con grande gusto, sono piane e sempre omogenee della sfumatura, chè sobria, lineare", G.B. Montini, Larte di Beuron, s. 34. 
zasadą nadziemskiej inspiracji. Zewnętrzna surowość form i oschłość scen są więc niczym więcej niż nieruchomym zawieszeniem kontemplacji, ekstazy: aby świat pozaziemski się objawił, potrzebne jest to ekstremalne skupienie ${ }^{19}$.

Sztuka Beuron odziera dzieło z otoczki słodkiego i mdłego pietyzmu oleodruków, które w latach dwudziestych XX wieku powoli zalewają rynek sztuki sakralnej. Co więcej może być pierwszym krokiem odrodzenia prawdziwej sztuki sakralnej. Mistyczna, prowadząca ku wierze, esencjalna, ikoniczna i symboliczna wpisuje się w nurt sztuki współczesnej, wychodzącej z muzeów na ulice. Sztuki popularnej, bliskiej człowiekowi dwudziestego wieku i rodzącej się Awangardy odrzucającej dotychczasowe style. ${ }^{20} \mathrm{~W}$ owej formie ma ona charakter dydaktyczny, gdzie symbolika chrześcijańska niczym nie zmącona prezentuje w sposób bezpośredni orędzie biblijne.

\section{ZAGROŻENIE FUTURYZMU}

Dwa lata po artykule dotyczącym szkoły w Beuron, Montini publikuje w pierwszym zeszycie „Arte Sacra” swoje przemyślenia na temat przyszłej sztuki sakralnej, objęte tytułem Su l'arte sacra futura. Będzie to jego pierwszy i jedyny artykuł opublikowany w tym czasopiśmie, którego komitet redakcyjny, złożony jest z dwunastu osób, wśród których są profesorowie Uniwersytetu Gregoriańskiego, krytycy sztuki czy też inżynierowie. Montini za pomocą metody problematycznej we właściwy dla siebie sposób stawiania pytań retorycznych, analizuje możliwości rozwoju sztuki sakralnej ${ }^{21}$. Artykuł nie jest jednak zwykłym i oderwa-

19 „Non distrae, quest’arte. Fa meditare, fa pregare. La mistica si è rivelata dietro le sue forme e la trasfigurazione, sommo principio della vita soprannaturale e del culto liturgico, è stato il suo principio artistico di sovrana ispirazione. La rigidezza esteriore delle forme e la freddezza delle scene non è quindi altro che la sospensione immobile della contemplazione, dell'estasi: perché un mondo ulteriore si riveli occorre questo estremo raccoglimento", G. B. Montini, Larte di Beuron, s. 37.

20 Por. G. L. Tusini, Una non facile conciliazione, s. 42.

${ }^{21}$ Por. F. Salamone, Perenne rivelazione dellarte cristiana. Per una teologia dellarte in Paolo VI, Palermo 2013, s. 42. 
nym od rzeczywistości zbiorem przemyśleń. Kilka miesięcy wcześniej, 23 czerwca 1931 r. na łamach "Gazzetta del Popolo” w Turynie zostaje opublikowany manifest futurystyczny pod tytułem Manifesto dell'arte sacra futura. Jego twórcy Filippo Tommaso Marinetti i Fillia (Luigi Colombo) wysuwają twierdzenia, iż do kreowania arcydzieł sztuki sakralnej nie jest konieczne praktykowanie religii katolickiej. Futuryzm proponuje zerwanie z dotychczasowym wpływem sztuki na wiernych, którzy mieliby w niej odnaleźć drogę ku Bogu i nawołuje do kompletnego odnowienia poprzez syntezę i dynamizm. Ponadto futuryści są przekonani, iż mogą wyrazić jasno dogmaty wiary katolickiej w nowym, energicznym mistycyzmie mającym swoje źródło w prędkości ${ }^{22}$. Tezy wysunięte przez Marinettiego i Fillię są kontynuacją Manifestu futurystycznego opublikowanego w pierwszym numerze "L'Italia futurista” z 1916 r. pod tytułem La nuova religione - morale della velocità ${ }^{23}$. Futuryzm będący ruchem świeckim, antyklerykalnym, antykościelnym i antychrześcijańskim nawołuje w nim do nowej religii. Teologia prędkości i postępu, ma zastąpić dotychczasową moralność chrześcijańską ${ }^{24}$. Aby lepiej zrozumieć obawy i myśli Montiniego, wyrażone w cytowanym artykule, wystarczy przytoczyć niektóre frazy z owego Manifestu z 1916 r.

Moralność chrześcijańska służyła rozwojowi życia wewnętrznego człowieka. Nie ma już racji bytu, ponieważ w całości wyzbyła się boskości. [...] Moralność chrześcijańska broniła struktury fizjologicznej człowieka przed nadmiarem zmysłowości. Ograniczała jego instynkty i je równoważyła. Moralność futurystyczna obroni człowieka przed rozkładem spowodowanym powolnością, pamięcią, analizą, wypoczynkiem, przyzwyczajeniem. [...] Jeśli modlić się oznacza być w kontakcie z boskością, to pędzić z wiel-

${ }^{22}$ Por. Fillia, F. T. Marinetti, Manifesto dell'arte sacra futura, „La Gazzetta del Popolo", 23 giugno 1931; Fillia, F. T. Marinetti, Manifesto dell'arte sacra futura, w: Filippo Tommaso Marinetti. Teoria e invenzione futurista, red. L. De Maria, Milano 1968, s. 201-205.

${ }_{23}$ Por. F. T. Marinetti, La nuova religione - morale della velocità, „L'Italia futurista”, 1 giugno 1916; F. T. Marientti, La nuova religione - morale della velocità, w: Manifesti del Futurismo, red. V. Birolli, Milano 2008, s. 165-170.

${ }^{24}$ Por. G. L. Tusini, Derive aeree della mistica: il demone del futurismo, w: Attraverso il tempo. Tersa di Gesù: la parola, il modello, leredità, red. E. Marchetti, Ravenna 2017, s. 220. 
ką szybkością oznacza modlitwę. Świętość koła i szyn. Trzeba uklęknąć na szynach, żeby modlić się do boskiej szybkości²5.

Futuryści widzą w stacjach kolejowych, w pociągach, w filmie, w wielkich dziełach inżynierii „miejsca zamieszkałe przez boskość”26 Przed bluźnierczymi hasłami futurystów, które dotykają wszystkich dziedzin życia i kultury, w tym sztuki sakralnej, stoi człowiek, który w swym życiu traktuje kulturę jako środek, uprzywilejowaną drogę do osiągnięcia celu, jakim jest dojrzała, kompletna i integralna osoba ludzka ${ }^{27}$.

\section{SZTUKA SAKRALNA WOBEC DEMONA FUTURYZMU}

Na wstępie Su l'arte sacra futura - artykułu czasopisma, którego celem ma być edukacja w dziedzinie sztuki, Montini stawia pytanie: „również do pobożnego i pacyficznego ogrodu sztuki sakralnej wdarłby się więc wzburzony demon futuryzmu?” ${ }^{28}$ Montini ocenia stan sztuki sakralnej, która w jego opinii powinna pełnić funkcję dydaktyczną. Tymczasem, pośród nowych idei i prądów artystycznych sztuka ta jest

nadal pełna pragnień i niepewności, ciągle dziecinna w niewłaściwie podejmowanych próbach, ciągle niedojrzała w pojmowaniu rzeczy wielkich i kompletnych, wciąż służebna wobec nie swoich reguł, nieznająca nadal tajemniczego Ducha Sakralnego Piękna, który ją przenika, aby uczynić ją żywą i wspaniałą 29 .

25 „La morale cristiana servi a sviluppare la vita interna dell'uomo. Non ha più ragione d'essere oggi, poiché sè vuotata di tutto il Divino. La morale cristiana difese la struttura fisiologica dell'uomo dagli eccessi della sensualità. Moderò i suoi istinti e li equilibrò. La morale futurista difenderà l'uomo dalla decomposizione determinata dalla lentezza, dal ricordo, dall'analisi, dal riposo e dall'abitudine. [...] Se preghare vuol dire comunicare con la divinità, correre a grande velocità è una preghiera. Santità della ruota e delle rotaie. Bisogna inginocchiarsi sulle rotaie per pregare la divina velocità". F. T. Marinetti, La nuova religione - morale della velocità, s. 165-166.

26 Por. F. T. Marinetti, La nuova religione, s. 167-168.

27 Por. P. Poupard, Le dialogue, Paul VI et les cultures contemporaines, s. 55.

28 "Anche nell'orto pio e pacifico dell'arte sacra sarebbe dunque entrato il demone agitato del futurismo?” G. B. Montini, Su l'arte sacra futura, „Arte Sacra” 1 (1931), s. 39. $29, \ldots[. .$.$] ancor piena tutta di desideri e d'incertezze, ancora bambina in mal riu-$ 
W krytyce skierowanej w stronę istniejących już wytworów sztuki sakralnej, Montini pyta o cel, do którego twórca i jego dzieło podążają ${ }^{30}$ :

Jeśli średniowiecze troszczyło się o ład w swej twórczości, jeśli Renesans próbował ubrać się w perfekcyjny humanizm, sugerowany przez klasyczny antyk [...] jeśli Barok próbował zewnętrznego efektu i zadziwiającej ekspresji, jeśli Romantyzm był wezwaniem do autentycznej sentymentalności [...] jaki będzie kierunek dominujący sztuki sakralnej naszego odnowionego i innowacyjnego wieku? ${ }^{31}$

Montini ma świadomość, iż są podejmowane przez artystów próby określenia owego kierunku i wskazuje cztery drogi, które zostały wybrane i zastosowane przez nich w twórczości.

Pierwsza $z$ nich jest rozwiązaniem wybieranym coraz powszechniej przez artystów. Mowa tu o „wyniosłym i otwartym odrzuceniu wytycznych, które z jednej strony nie dostrzegają geniusza naszego wieku, z drugiej nie osiągają ani oryginalności formy sakralnej, ani przydatności do sprawowania kultu religijnego w ścisłym sensie, który to odrzuca dzieła błędne w wyrażeniu myśli i treści sakralnej”32.

Druga to via lata, poboczna,

w której rozwinęła się pewna spontaniczna sztuka sakralna, tzn. obca życiu mistycznemu i hierarchicznemu Kościoła, kierująca się każdego

sciti tentativi, ancora acerba nel concepir cose grandi e complete, ancora servile a regole non sue, e ignara tuttora donde l'arcano Spirito del Bello Sacro soffi a renderla agile e splendida". G. B. Montini, Su l'arte sacra futura, s. 40.

${ }^{30}$ Por. G. B. Montini, Su l'arte sacra futura, s. 40.

31 „Se il Medio-Evo ebbe prevalente una preoccupazione di ordine nella sua opera artistica; se il Rinascimento cercò di rivestire di umanità perfetta, quale l'antichità classica suggeriva, il fatto cristiano, cedendo a tendenza umanistica e decorativa; se il Barocco cercò l'effetto esteriore e meraviglioso dell'espressione; se il Romanticismo fu un richiamo alla sincerità sentimentale; quale sarà l'indirizzo dominante l'arte sacra del nostro secolo rinnovato e rinnovatore?" G. B. Montini, Su l'arte sacra futura, s. 40.

32 „Si vien risolvendo con il rifiuto sempre più fiero ed aperto agli indirizzi, che, per un verso, non indovinano il genio del nostro tempo, per un altro, non raggiungono nè l'autenticità della forma sacra, nè l'utilità d'un impiego per un qualche culto realmente religioso, che rifiuta di servirsi di opere difettose nell'espressione sacra, o nel contenuto sacro". G. B. Montini, Su l'arte sacra futura, s. 41. 
dnia ku pustce duchowej. Jest to droga, którą podążają ci, którzy ją stosują bez uznania kultury religijnej i bez pomocy wynikającej z praktyki wiary. To sztuka świecka, która nie poprzez reformę, ale przez proste przeniesienie idei z psychologii i techniki na przedmioty sakralne, które wydają się być przebrane w szaty, nadające się do wszystkiego ale nie do interpretacji sakralności ${ }^{33}$.

Według Montiniego, w poprzednich epokach artysta czerpał ze źródła wiary i religijności - „pomimo, że dziś atmosfera jest pełna idei, zwyczajów, odczuć, pragnień, nie tylko dalekich, ale przeciwnych duchowi chrześcijańskiemu, naturalnym jest, iż ta droga nie może przynieść nic więcej niż imitację, formalizm, wysiłek, fragmentaryczność w sztuce sakralnej" 34 .

Trzecią drogą, jest ta, w której artysta wyraża bardziej siebie aniżeli orędzie płynące $\mathrm{z}$ wiary. „Biegnie on w kierunku błąkając się tam, gdzie nikt go nie rozumie lub gdzie go spotyka nagana za wypaczenie tego sacrum, które cały lud zna i otacza czcią, a Kościół naucza i broni” ${ }^{35}$.

Czwartą drogą, jest droga tzw. zawracania, powrotu do tego, co już było. „Podążają nią ci, którzy mają wątpliwości co do otrzymania od współczesnego świata autentycznej i genialnej inspiracji odnośnie do sztuki sakralnej; są oni przekonani, iż przeszłość posiadała ową czystą i bogatą inspirację. I ci właśnie chętnie kopiują artystów przeszłych epok”36. Rozwój

33 „La via lata, ma non maestra, nella quale sè messa certa arte sacra spontanea, cioè estranea alla vita mistica e gerarchica della Chiesa, appare ogni giorno di più diretta verso il deserto. Ed è la via seguita da quanti applicano, senza il vaglio d'una cultura religiosa e senza il sussidio d'una intima pratica di fede, l'arte profana, mediante una sempice trasposizione, e non riforma, di psicologia e di tecnica, a soggetti sacri; i quali risultano così travestiti di abiti tutt’altro che adatti a interpretare il sacro, intimo e nascosto". G. B. Montini, Su l'arte sacra futura, s. 41.

34 „Mentre oggi dovunque l'atmosfera è gonfia di idee, costumi, sentimenti, desideri, non solo lontani, ma contrari allo spirito cristiano. Ed è naturale che questa via non può portare che imitazione, formalismo, stento, frammentarietà nell'arte sacra". G. B. Montini, Su l'arte sacra futura, s. 41.

35 „e corre vagando così dove nessuno più lo comprende, o dove lo colpisce il rimprovero d'aver travisato quel sacro che tutto un popolo conosce e venera, e una Chiesa insegna e difende". Tamże.

36 „Poi, c’è la via, diciamo così, a ritroso, percorsa da quelli che sono altrettanto sfiduciati di ricever dal mondo moderno genuina e geniale ispirazione d'arte sacra, quanto 
studiów nad historią sztuki sprzyja działalności artystów idących za ideą powielania przeszłości, co spotyka się z ogólna aprobatą. Jednakże, według młodego kapłana owo powielanie nie ukazuje duchowości epoki, w której obecnie znajduje się Kościół a jedynie przywołuje prądy już znane ${ }^{37}$.

Montini, kontynuując rozważania na temat idei wdrażanych przez artystów na polu sztuki sakralnej nie waha się „podzielać przekonań tych, którzy podtrzymują tezę, iż celem przyszłej sztuki sakralnej byłaby ekspresja realizmu teologicznego i dogmatycznego, a przez to ontologicznego, nadprzyrodzonego i mistycznego naszej religii”" ${ }^{38}$. Tę myśl osadza głęboko w rzeczywistości w wieku, który, jak odnotowuje, jest wiekiem nauki, refleksji i krytyki, historii i badań nad klasyfikacją, w końcu wiekiem istoty $^{39}$. Zdaniem Montiniego,

obowiązkiem współczesnej sztuki sakralnej jest zdecydowane podążanie za istotą katolicyzmu oraz mierzenie się z nim, próba wyrażenia go w swoim języku, bowiem dziś w religii poszukuje się esencjalności, oryginalności; tego co zasadnicze; tego co pierworodnie witalne. Jeśli sztuka będzie miała przed oczyma to zamierzenie, podąży prosto i daleko. Będzie miała rzesze współczesnych i inteligentnych naśladowców ${ }^{40}$.

Ów realizm zatem jest drogą, którą powinien kroczyć artysta tak, aby nie zatracić się w chaosie wielu wymieszanych ze sobą nurtów. Ewidentne jest, iż dla Montiniego wiara i praktyka religijna artysty są fundamentem, na którym ma on bazować swoją kreatywność. Dzieło w ten

convinti che il passat ne possedeva vena limpida e ricca. E questi volentieri ricalcano i sentieri degli artisti di altri tempi”. Tamże, s. 42.

37 Por. Tamże.

38 „Ma non esito a condividere l'idea di quelli che sostengono che la meta dell'arte sacra futura sia l'espressione del realismo teologico e dogmatico, e perciò ontologico, soprannaturale e mistico, della nostra religione”. Tamże.

39 Por. Tamże, s. 42-43.

$40, \ldots[.$.$] nostra affermazione che sostiene dover l'arte sacra moderna dirigersi$ risolutamente verso l'essenza del cattolicesimo, e con quella misurarsi, quella tentare di esprimere nel suo linguaggio, poichè anche nella religione oggi si cerca l'essenziale, l'originario; ciò chè sostanziale; ciò chè primieramente vitale. E, se l'arte camminerà con questa meta davanti agli occhi, andrà diritto e lontano, e avrà folle di spiriti moderni e intelligenti che la seguiranno". Tamże, s. 43. 
sposób uzyskane nie będzie jedynie wytworem ludzkiego geniuszu, ale aktem modlitwy i medytacji ${ }^{41}$.

Podsumowując, sztuka ma pomagać w modlitwie, wyzwalać się z każdego ograniczenia spowodowanego zbytnim przywiązaniem do przeszłości. Sztuka ma zmagać się z problemem przedstawienia niewidzialnego. Aby to uzyskać należy zacząć od mistyki, owego niewidzialnego Światła. Prawdziwa sztuka sakralna „rodzi się z artysty pobożnego i wierzącego, modlącego się, proszącego, który czuwa w milczeniu i w szczodrości oczekując na swoje Zesłania Ducha Świętego" ${ }^{42}$. Ma on do spełnienia, według Montiniego, ważną misję:

Widać wreszcie jak artysta chrześcijański, po tym jak był uległy i posłuszny Przykazaniom Bożym, powołany zostaje by stać się prekursorem nowych czasów, gdzie tylko piękno przez niego przypieczętowane sprawia, że rzeczy stają się lepsze. Jako że prawdziwie uważam, iż przyszedł czas na naszych artystów chrześcijańskich, by przygotowali poprzez nowe dzieła nowy stan ducha, gdzie zostanie złączona z Chrystusem nasza duchowa jedność, obecnie tak rozdarta. Jedność, która połączy w należytej harmonii wrażenie i wyraz, świat zewnętrzny i wewnętrzny, ducha i materie, dusze i ciało, Boga i człowieka. Pokój jest się w pieśni sztuki pobożnej ${ }^{43}$.

Tak więc wiara i sztuka są dla Montiniego dwoma kanałami, dzięki którym człowiek może przedostać się do świata mistyki chrześcijańskiej, a artysta wierzący jest prorokiem drogi ku spotkaniu z nieskończonością. Jednak, jak twierdzi G. L. Tusini, w rzeczywistości demoniczny duch sztuki futurystycznej, przywołany na początku artykułu, jest jedynie od-

${ }^{41}$ Por. G. L. Tusini, Una non facile conciliazione, s. 44-45.

42 "Quando ciò si comprende e si vuole, si vede anche dove e come nasca la vera arte sacra: all'artista pio e credente, orante, desiderante, che veglia nel silenzio e nella bontà, in attesa della sua Pentecoste". G. B. Montini, Su l'arte sacra futura, s. 44.

43 „Si vede finalmente come l'artista cristiano, dopo esser stato docile e umile seguace dei comandi di Dio, sia chiamato trasformarsi in precursore di tempi nuovi, che solo la belezza da lui sigillata nelle cose può rendere migliori. Poichè davvero penso che tocchi ai nostri artisti cristiani a preparare con le opere loro uno stato di spirito dove si ricomponga in Cristo la nostra spirituale unità, ora lacerata; l'unità, dico, che riconcilii in debita armonia l'impressione e l'espressione; il mondo interno e l'esterno; lo spirito e la materia; l’anima e la carne; Dio e l'uomo. Pace è nel canto dell'arte pia”. G. B. Montini, Su l'arte sacra futura, s. 44-45. 
powiedzią na opublikowany wcześniej Manifest. Obawy wysnuwane przez młodego kapłana, nie mają pokrycia w rzeczywistości, w której futuryści, owszem tworzą sztukę niezrozumiałą i nienadająca się do kultu, jednak liczba jej dzieł z pewnością nie jest duża, a już tym bardziej nie zostaje ona umieszczona w kościołach ${ }^{44}$.

\section{BIBLIOGRAFIA}

Fillia, Marinetti F. T., Manifesto dell'arte sacra futura, „La Gazzetta del Popolo”, 23 giugno 1931

Fillia, Marinetti F. T., Manifesto dell'arte sacra futura, w: Filippo Tommaso Marinetti. Teoria e invenzione futurista, red. L. De Maria, Milano 1968, s. 201-205.

Lenz, D., Canone Divino. Larte e la regola della Scuola di Beuron, red. P. Martore, Castelvecchi 2015.

Marientti, F. T., La nuova religione - morale della velocità, w: Manifesti del Futurismo, red. V. Birolli, Milano 2008, s. 161-170.

Marinetti, F. T., La nuova religione - morale della velocità, „L'Italia futurista”, 1 giugno 1916.

Montini, G. B., Larte di Beuron, „Istituto Paolo VI. Notiziario” 16 (1988), s. 7-10.

Montini, G. B., L'arte di Beuron, „Studium” 25 (1929) 1, s. 33-37.

Montini, G. B., Lettere ai familiari (1919-1943), t. II (1928-1943), red. N. Vian, Brescia-Roma 1968.

Montini, G. B., Spunti apologetici, w: Scritti giovanili, red. C. Trebeschi, Brescia 1979, s. $138-139$.

Montini, G. B., Su larte sacra futura, „Arte Sacra” 1 (1931), s. 39-45.

Poupard, P., Le dialogue, Paul VI et les cultures contemporaines, w: Le jeurnée détudies Paris, 13 décembre 2005, red. G. Archetti, Brescia 2007, s. 53-64.

Salamone, F., Perenne rivelazione dellarte cristiana. Per una teologia dellarte in Paolo VI, Palermo 2013.

Segnantini, G., Pensieri d'artisti, w: Archivi del divisionismo, red. M.T. Fiori, Roma 1969, t. I, s. 337.

Tusini, G. L., Derive aeree della mistica: il demone del futurismo, w: Attraverso il tempo. Tersa di Gesù: la parola, il modello, leredità, red. E. Marchetti, Ravenna 2017, s. 219-234.

Tusini, G. L., Una non facile conciliazione, w: Vita culturale e idee sullarte negli anni del Vaticano II, red. E. Marchetti, G. L. Tusini, Roma 2011, s. 29-69.

Vismara, S. M., La nuova arte di Beuron, Roma 1913.

${ }^{44}$ Por. G. L. Tusini, Derive aeree della mistica: il demone del futurismo, s. 220. 